\title{
Pharmaciana
}

Vol.10, No.3, Nov 2020, Page. 325-334

ISSN: 2088 4559; e-ISSN: 24770256

DOI: $10.12928 /$ pharmaciana.v10i3.18091

\section{Antiobesity activity of Bambu Tali (Gigantochloa apus (Schult.) Kurz) leaves tea in Wistar rats}

\author{
Desi Ambarwati, Sapto Yuliani*, Arsyannur Pratiwi \\ Department of Pharmacology, Faculty of Pharmacy, Universitas Ahmad Dahlan \\ Jl.Prof. Dr. Soepomo, Janturan, Yogyakarta, Indonesia
}

\begin{abstract}
Obesity is an increase in body weight that exceeds normal and the risk of serious illness. Bambu Tali leaves (Gigantochloa apus (Schult.) Kurz) contain flavonoids, tannins, and saponins, which can inhibit the absorption of fatty acids in the digestive tract and excrete them through feces to lose weight. This study examines the tea activity of the Bambu Tali leaves in inhibiting weight gain, total cholesterol, and triglyceride levels of obese Wistar rats fed with a high-fat diet (HFD). A total of 30 Wistar rats were divided into 6 groups: normal control (standard feed), negative control (HFD), positive control (HFD + Orlistat), and 3 groups of tea doses of Bambu Tali leaves (HFD + 360, HFD + $720, \mathrm{HFD}+1440 \mathrm{mg} / \mathrm{kg} \mathrm{BW}$ ). HFD was given together with the Bambu Tali leaf tea for 35 days. On the 36th day, the blood sample was taken to measure cholesterol and triglyceride levels. The weighing was conducted weekly. The results showed that giving HFDincreased body weight significantly, total cholesterol, and triglyceride levels ( $\mathrm{p}<0.05$ ). Bambu Tali leaf tea at doses of 720 and $1440 \mathrm{mg} / \mathrm{kg} \mathrm{BW}$ could significantly inhibit weight gain $(\mathrm{p}<0.05)$. Bambu Tali leaf tea with doses of 360, 720, and 1440 $\mathrm{mg} / \mathrm{kg} \mathrm{BW}$ can also inhibit the increase in total cholesterol levels $(\mathrm{p}<0.05)$. Meanwhile, the inhibition of a significant increase in triglyceride levels $(p<0.05$ ) only occurs at a dose of $1440 \mathrm{mg} / \mathrm{kg} \mathrm{BW}$. This study concludes that Bambu Tali leaf tea has antiobesity activity by inhibiting weight gain, total cholesterol levels, and plasma triglycerides of Wistar rats.
\end{abstract}

Keywords: Gigantochloa smear (Schult.) Kurz, obesity, body weight, cholesterol, triglycerides

\footnotetext{
*Corresponding author:

Sapto Yuliani

Department of Pharmacology, Faculty of Pharmacy, Universitas Ahmad Dahlan

J1.Prof. Dr. Soepomo, Janturan, Yogyakarta, Indonesia

Email:sapto.yuliani@pharm.uad.ac.id
} 


\section{INTRODUCTION}

Obesity is a condition where fat accumulation in adipose tissue is more than usual due to the greater amount of food consumed than the body's energy needs. Obesity is characterized by a body mass index (BMI) value greater than $27 \mathrm{~kg} / \mathrm{m}$, whereas a BMI is $27 \mathrm{~kg} / \mathrm{m}$ (Wells et al., 2017). Fat accumulation in adipose tissue can be caused by food consumption containing fat, protein, and carbohydrates (Rismawati et al., 2012). This can be related to several diseases such as diabetes mellitus and cardiovascular disease through increased levels of triglycerides, total cholesterol, lowdensity lipoprotein (LDL) and high-density lipoprotein (HDL), blood sugar, and blood pressure. The study by Sudikno et al. (2017) explains that hypercholesterolemia that occurs in obesity is caused by adipose cells not being able to adequately store triglycerides, increasing triglyceride levels followed by an increase in LDL levels and a decrease in HDL levels in the blood. Obesity also increases triglycerides' production due to increased excessive VLDL formation and can increase blood LDL levels (Rantung et al., 2014).

One of the drugs that can be used as antiobesity is orlistat. However, the use of orlistat is still limited because of its relatively high price. Besides, it can also cause side effects on the digestive tract, digestive function, and liver (Wells et al., 2017). It is necessary to have other alternatives to treat obesity.

Bambu Tali (Gigantochloa apus (Schult.) Kurz) is mostly used by the community as raw material for building and woven crafts. However, the Bambu Tali plant parts can also be used as traditional medicine. Not only the roots and stems, but Bambu Tali leaves can also be used as traditional medicine (Sujarwo et al., 2010). According to Rusliyani (2013), Bambu Tali leaves contain flavonoids, saponins, tannins, triterpenoids, alkaloids, glycosides, and phenolics. Based on George and Nimmi's (2011) research, most plants with an antiobesity activity contain saponins, tannins, flavonoids, and alkaloids. These compounds inhibit the pancreatic lipase enzyme activity so that it slows down the absorption of fatty acids in the digestive tract and can ultimately reduce triglyceride levels, total blood cholesterol, and body weight (Hidayat et al., 2015).

One of the traditional medicinal preparations is tea. Tea is the steeping of leaves or flowers that have undergone a drying or fermentation process to deactivate the enzyme. Tea is a form of beverage product popular with the public because it is easy to serve, and there is a fresh sensation after drinking it. This study aims to determine the tea activity of Bambu Tali leaves in inhibiting weight gain, total cholesterol, and serum triglyceride levels of obese Wistar rats given a high-fat diet (HFD).

\section{MATERIALS AND METHODS Materials}

The materials used were Bambu Tali leaves taken on the order of 3-4 from the shoots of the leaves and obtained from Bibis District, Bantul, Yogyakarta. aquadest (Brataco), $\mathrm{FeCl}_{3} 1 \%$ (Merck), Ethanol (Merck), CHOD-PAP reagent kit (DiaSys), GPO-PAP reagent kit (DiaSys). The high-fat dietary ingredients were standard feed (BR2, PT. Comfeed), chicken egg yolk, butter (Blueband), beef fat, $0.05 \%$ propylthiouracil (PTU, Dexa Medica), and orlistat (Xenical).

\section{Plant determination}

Plant determination was carried out at the Laboratory of Biology, Faculty of Applied Science and Technology, Universitas Ahmad Dahlan, Yogyakarta. The plant is tested by taking one part of the stem and leaf from the Bambu Tali tree.

\section{Making Bambu Tali leaves tea}

The Bambu Tali leaves were washed under running water and sorted. Then the Bambu Tali leaves were dried in the oven. Simplicia was refined using a blender and sieved using a 20 mesh sieve until the desired powder was obtained. Two grams of Bambu Tali leaf powder were weighed and put 
into a teabag. Twenty-eight milliliters of boiling water were then added for a dose of $360 \mathrm{mg} / \mathrm{kg} \mathrm{BW}$; $14 \mathrm{ml}$ for $720 \mathrm{mg} / \mathrm{kg} \mathrm{BW}$; and $7 \mathrm{ml}$ for $1440 \mathrm{mg} / \mathrm{kg} \mathrm{BW}$. Teabag was dipped 15 times and allowed to stay for 5 minutes.

\section{Phytochemical screening test}

Flavonoid identification

Two milliliters of tea solution of Bambu Tali leaves were steamed until dry. It was then dissolved in $50 \%$ methanol. After that, $4-5 \mathrm{~mL}$ of $\mathrm{Mg}$ and concentrated $\mathrm{HCl}$ were added. The red solution indicates the presence of flavonoids (Habibi et al., 2018).

Saponin identification

Five milliliters of tea solution of Bambu Tali leaves were added by $5 \mathrm{~mL}$ of hot water, then cooled and shaken vigorously for 10 seconds until foam formed. If the foam did not disappear after adding 1 drop of $\mathrm{HCl}$, it indicated saponin compounds' presence (Simaremare, 2014).

Tannin identification

Five milliliters of tea solution of bamboo Tali leaves were added with $1 \mathrm{~mL}$ of $10 \% \mathrm{FeCl} 3$ solution. The dark blue-black or greenish-black color that was formed indicated tannin compounds' presence (Simaremare, 2014).

\section{Making high-fat diet (HFD)}

High fat dietary feed (HFD) was prepared with the following composition: Standard feed $300 \mathrm{~g}$, $20 \mathrm{~g}$ chicken egg yolk, $100 \mathrm{~g}$ butter, $10 \mathrm{~g}$ beef fat, and $0.05 \%$ PTU. The ingredient was mixed into a dough, then milled to obtain a pellet form, and dried in an oven at a temperature of $50^{\circ}$ for 3 days (Rini, 2012).

\section{Treatment of test animals}

This study has obtained ethical approval from the Research Ethics Committee, Universitas Ahmad Dahlan, with approval number 011904027. A total of 30 Wistar rat 2.5-3 months old with a bodyweight of 140-210 $\mathrm{g}$ were obtained from the Research and Testing Laboratory (LPPT), Universitas Gadjah Mada, Yogyakarta. Rats were grouped into 6 groups as follows: Normal control group rats were given standard feed, negative control group rats were given HFD feed, positive control group rats were given orlistat dose $32.4 \mathrm{mg} / \mathrm{kg} \mathrm{BW}$ (HFD + Orlistat), and treatment group rats were given HFD and Bambu Tali leaves tea doses of 360 (HFD+360), 720 (HFD+720), and $1440 \mathrm{mg} / \mathrm{kg}$ BW (HFD+1440) orally. The oral administration of Tali Bambu leaf and HFD for 35 days. Weights were carried out on days $0,7,14,21,28$, and 35 . Blood samples were taken on day 36 , for measuring serum cholesterol and triglyceride levels.

\section{Determination of total cholesterol levels}

Total cholesterol levels were measured using the cholesterol oxidase phenol aminophenazone (CHOD-PAP) method. A total of $1.5 \mathrm{~mL}$ of blood was centrifuged for 15 minutes at a speed of 3,000 $\mathrm{rpm}$. The serum was then separated. Ten microliters of serum were then added with $1000 \mu \mathrm{L}$ CHODPAP reagent and homogenized using vortex for 15 minutes. Furthermore, the mixture was incubated in an incubator at $37^{\circ} \mathrm{C}$ for 10 minutes. Rat cholesterol levels $(\mathrm{mg} / \mathrm{dL})$ were read using a UV-Vis spectrophotometer at a wavelength of $546 \mathrm{~nm}$ (Anas et al., 2017).

\section{Determination of triglyceride levels}

Triglyceride levels were measured by the glycerol-3-phosphate oxidase-peroxidase amino antipyrine (GPO-PAP) method. A total of $10 \mu \mathrm{L}$ of serum was added with $1000 \mu \mathrm{L}$ of GPO-PAP reagent. The mixture was then homogenized using a vortex for 15 minutes. Furthermore, the mixture 
was incubated at $37^{\circ} \mathrm{C}$ for 10 minutes. Rat triglyceride levels $(\mathrm{mg} / \mathrm{dL})$ were read using a UV-Vis spectrophotometer with a wavelength of $500 \mathrm{~nm}$ (Rini, 2012).

\section{Data Analysis}

The data obtained were analyzed statistically using the Shapiro Wilk to determine the normality of the data and Levene's test to determine the homogeneity. Data of body weight, cholesterol and triglyceride levels were statistically analyzed using One Way Analysis of Variance (ANOVA) followed by post hoc Tukey's Honestly Significant Differences (HSD Test) with a significance level of 0.05 (Yuniarti et al., 2016). The analysis was conducted using SPSS program version 21.

\section{RESULTS AND DISCUSSION}

Plant determination

Based on the results of plant determination that has been carried out, it shows that the plant identified as a Bambu Tali plant (Gigantochloa apus (Schult.) Kurz) from the Poaceae family.

\section{Results of phytochemical screening}

The phytochemical screening results showed that the tea with Bambu Tali leaves contained flavonoids, saponins, and tannins. These results are supported by the study of Romansyah et al. (2019), which showed that the Bambu leaf extract contained flavonoids and alkaloids and was positive for saponin and tannin compounds. Rusliyani (2013) also reported that the Bambu leaf extract contained alkaloids, saponins, triterpenoids, and glycosides and weakly contained phenolic compounds, flavonoids, and tannins. The results of the phytochemical screening test are shown in Table 1.

Table 1. Phytochemistry screening test result of Bambu Tali

(Gigantochloa apus (Schult.) Kurz) leaf tea

\begin{tabular}{cc}
\hline Phytochemical compounds & Result \\
\hline Flavonoid & + \\
Tannins & + \\
Saponins & + \\
\hline
\end{tabular}

Note: (+) : Positive

\section{Bambu Tali Tea inhibited the weight gain of rat}

In this study, HFD feed was given together with Bambu Tali leaf tea for 35 days. This is intended to determine the protective effect of the Bambu rope tea leaves against weight gain to prevent obesity. The weight measurement results showed a change in body weight, which tended to increase up to day 35 in the HFD only group. Bambu Tali tea administration with 720 and $1440 \mathrm{mg} / \mathrm{kg} \mathrm{BW}$ doses showed weight loss on days 28 and 35 but not at doses of $360 \mathrm{mg} / \mathrm{kg}$ BW (Figure 1). The results of statistical tests on the difference in body weight at the beginning and at the end of the treatment showed that giving HFD could significantly increase the bodyweight of rats and could be reduced by orlistat, and the increase was inhibited by the provision of Bambu Tali tea (Table 2). 


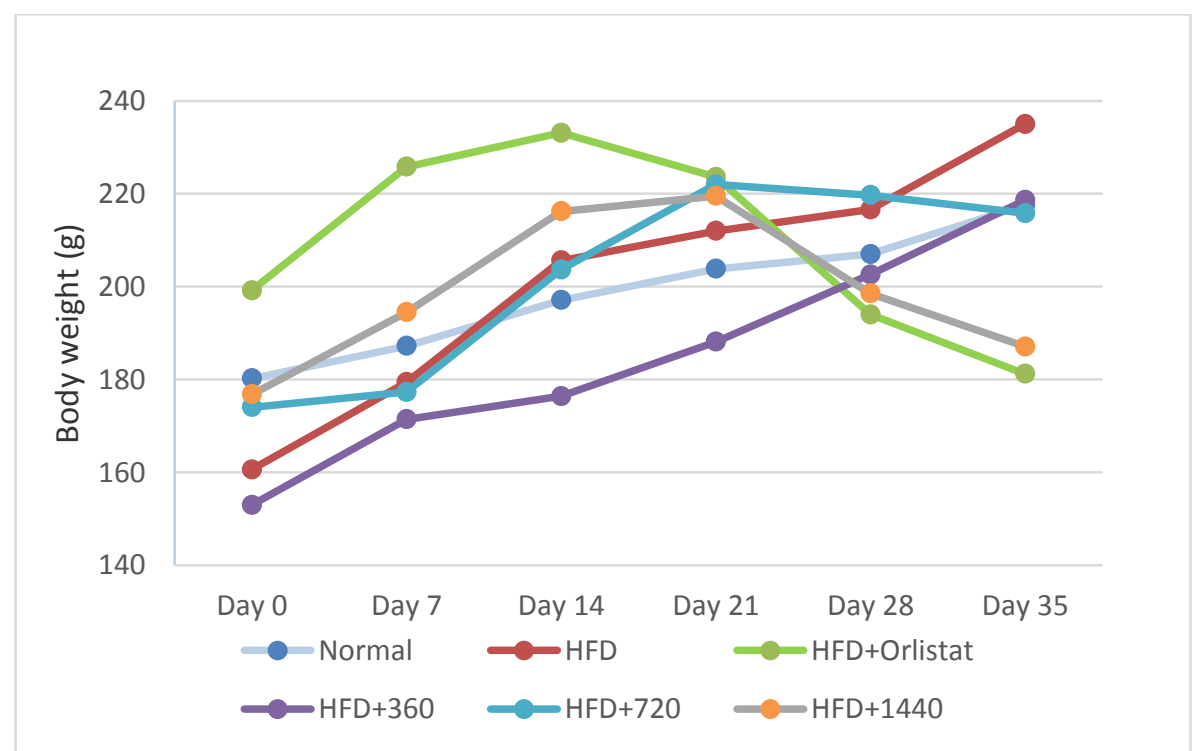

Figure 1. The mean of 'rat's body weight measured every week in all groups after administration of Bambu tali leaf tea and high-fat diet

Table 2. Mean of difference of 'rat's body weight at day 35 after administration of Bambu Tali tea and high-fat diet

\begin{tabular}{llll}
\hline \multicolumn{1}{c}{ Groups } & \multicolumn{2}{c}{$\begin{array}{c}\text { Mean body weight } \pm \text { SD } \\
(\mathbf{g})\end{array}$} & $\begin{array}{l}\text { Diiference } \\
\text { (mean } \\
\text { SD) }\end{array}$ \\
\hline Normal & \multicolumn{1}{c}{ Day 0 } & \multicolumn{1}{c}{ Day35 } \\
HFD & $180.2 \pm 5.67$ & $217.6 \pm 6.18$ & $+37.4 \pm 4.75^{*}$ \\
HFD+Orlistat & $160.6 \pm 9.15$ & $235.0 \pm 23.55$ & $+74.4 \pm 17.10$ \\
HFD+360 & $199.2 \pm 11.92$ & $181.2 \pm 21.79$ & $-16.0 \pm 19.02^{*}$ \\
HFD+720 & $153.0 \pm 13.65$ & $218.6 \pm 10.03$ & $+65.6 \pm 17.16$ \\
HFD+1440 & $174 \pm 2.44$ & $215.8 \pm 7.27$ & $+41.8 \pm 8.51^{*}$ \\
\hline
\end{tabular}

Notes: $* \mathrm{p}<0.05$ significantly different from HFD group
$(+)$ : an increase
$(-):$ a decrease

Test animals are said to be obese if there is an increase in body weight $>20 \%$ of the initial body weight (Patonah et al., 2017; Shiyan et al., 2017; Yuniarto et al., 2015). In this study, HFD administration caused an increase in body weight of rats by $46 \%$. According to Baraas (2003), high consumption of fat and carbohydrates will increase the amount of fat in the adipose tissue, especially those under the skin and abdominal cavity. This is because any excess amount of fat and carbohydrates; if not used immediately, they will be stored in the adipose tissue in the form of triglycerides. When needed, the triglycerides will be hydrolyzed into free fatty acids and glycerol. These free fatty acids are then oxidized to produce energy. In general, only $3 \%$ of total dietary glucose can be stored as glycogen in the liver and muscles, 30\% is stored as triglycerides, and $67 \%$ is burned directly as energy. Excess fat in the form of triglycerides in the adipose tissue under the abdominal cavity skin is what causes weight gain.

This study's results indicate that administration of tea with Bambu Tali leaves doses of 720 and $1440 \mathrm{mg} / \mathrm{Kg} \mathrm{BW}$ was able to inhibit the increase in body weight, which was significantly different from the HFD group ( $\mathrm{p}<0.05$ ). Bambu Tali tea contains saponin and flavonoid compounds that can 
inhibit the lipase enzyme in the digestive tract, thereby preventing the absorption of fat in the intestine. The fat that is not absorbed will come out together with feces (Hidayat et al., 2015). Apart from that, the tea with Bambu Tali leaves also contains tannin compounds that can precipitate the proteins in the small intestine's surface - thus reducing food absorption. Thus the process of obesity can be inhibited (Nurrachmawati, 2017).

In this study, the administration of orlistat inhibited weight gain, which was $16 \mathrm{~g}$ from the initial body weight. This is because orlistat works to absorb fat and change body fat metabolism by blocking the protein lipase enzyme's work, which works to break down fat, so that fat is excreted out of the body through feces. Fat can be absorbed if it has been converted by lipase into fatty acids from foods that are not hydrolyzed into free fatty acids and glycerol. Therefore, some fat is not absorbed by the intestines and causes inhibition of body weight gain (Tjay and Rahardja, 2008)

\section{Bambu Tali tea prevents an increase in total blood cholesterol levels}

According to a study, obesity can cause lipid metabolism disorders characterized by abnormalities of the lipid profile in the plasma, such as high levels of total cholesterol and triglycerides and low levels of High-Density Lipoprotein (HDL) cholesterol. The results of measuring total cholesterol levels are shown in Table 3.

Table 3. Mean of total cholesterol levels $(\mathrm{mg} / \mathrm{dL})$ of rats at day 35 after administration of Bambu Tali tea and high-fat diet

\begin{tabular}{ll}
\hline \multicolumn{1}{c}{ Groups } & $\begin{array}{l}\text { Mean total cholesterol level } \pm \text { SD } \\
(\mathbf{m g} / \mathbf{d L})\end{array}$ \\
\hline Normal & $64.82 \pm 3.34^{*}$ \\
HFD & $120.32 \pm 8.32$ \\
HFD+Orlistat & $117.53 \pm 7.27$ \\
HFD+360 & $101.55 \pm 7.14^{*}$ \\
HFD+720 & $85.29 \pm 4.87^{*}$ \\
HFD+1440 & $66.45 \pm 6.31^{*}$ \\
\hline
\end{tabular}

Note: $* p<0.05$ significantly different with HFD group

Table 3 shows that HFD causes an increase in total cholesterol levels significantly different from the normal group ( $\mathrm{p}<0.05$ ). This is because HFD contains triacylglycerols, which can increase the concentration of chylomicrons in plasma so that it can increase the formation of very low-density lipoprotein (VLDL), intermediate-density lipoprotein (IDL), and low-density lipoprotein (LDL). This condition causes a disturbance in the balance of cholesterol storage and transport in peripheral tissues. Increased storage of dietary cholesterol (exogenous cholesterol) in the peripheral tissue causes a decrease in the concentration of high-density lipoprotein (HDL), which has the role of inducing the excretion of cholesterol from peripheral tissues. This causes an increase in total cholesterol levels in the HFD group (Harsa, 2014). In addition, egg yolk in HFD feed plays a vital role in accelerating the increase in cholesterol levels because it has a cholesterol content of around $250 \mathrm{mg} / \mathrm{egg}$ (Wirawan, 2018). The lecithin content also acts as an emulsifier so that it helps mix oil/fat and water in the HFD composition (Sarifudin et al., 2015). The addition of propylthiouracil (PTU) to HFD is intended to increase cholesterol levels and increase body weight. This is because propylthiouracil functions to increase cholesterol levels endogenously by reducing thyroid hormone synthesis. Increased thyroid hormone can reduce the concentration of cholesterol, phospholipids, and triglycerides in the blood by increasing cholesterol secretion, thereby increasing the amount of cholesterol (Guyton and Hall, 2007). PTU can also interfere with the functions of Apo-A-I and Apo-A-IV, which are responsible for the formation of new HDLs. Apo-A-I and Apo-A-IV are the main apoproteins of HDL and are related to 
chylomicrons. If these apoproteins are confused, it will disrupt HDL formation, thereby affecting total cholesterol levels in the body (Shin and Osborne, 2003). In this study, rats also get limited space, so that the peripheral tissue's energy is reduced, resulting in rats becoming fat (Zulviana et al., 2017).

The administration of tea with doses of 360,720 , and $1440 \mathrm{mg} / \mathrm{kg}$ BW of Bambu Tali leaves prevented an increase in cholesterol levels in rats given HFD. The tea of Bambu Tali leaves contains flavonoid compounds that work to reduce cholesterol levels from the blood by inhibiting the enzyme 3-hydroxyl 3-metalhlutarilkoenzim A reductase so that it can have an effect on lowering cholesterol levels and works to inhibit the absorption of fatty acids by inhibiting pancreatic lipase in the digestive tract (Tibe et al., 2018). However, giving orlistat in this study did not show cholesterol levels that were significantly different from the HFD group. This is because the mechanism of action of orlistat cannot inhibit the metabolism of total cholesterol in the body so there is no inhibition of cholesterol metabolism (Kurnia, 2014).

\section{Bambu Tali tea prevents an increase in triglyceride levels}

In this study, the HFD administration can also increase blood triglyceride levels). However, only Bambu Tali tea with a dose of $1440 \mathrm{mg} / \mathrm{kg} \mathrm{BW}$ and orlistat reduced triglyceride levels (Table 4).

Table 4. Mean of total triglyceride levels $(\mathrm{mg} / \mathrm{dL})$ of rats at day 35 after administration of Bambu Tali tea and high-fat diet

\begin{tabular}{ll}
\hline \multicolumn{1}{c}{ Groups } & $\begin{array}{l}\text { Mean of triglyceride } \\
\text { levels } \pm \text { SD }(\mathbf{m g} / \mathbf{d L})\end{array}$ \\
\hline Normal & $82.13 \pm 15.92^{*}$ \\
HFD & $119.03 \pm 29.07$ \\
HFD+Orlistat & $71.84 \pm 7.44^{*}$ \\
HFD+360 & $130.10 \pm 23.26$ \\
HFD+720 & $111.84 \pm 23.14$ \\
HFD+1440 & $82.16 \pm 20.08^{*}$ \\
\hline Note: $* p<0,05$ significantly different with HFD group
\end{tabular}

The increase in triglyceride levels due to HFD administration is caused by a high-fat diet containing neutral fats that will be broken down into monoglycerides and free fatty acids in the digestive process. Through intestinal epithelial cells, monoglycerides and fatty acids will be synthesized back into triacylglycerol molecules, which will enter the lymph in the form of chylomicrons. High chylomicron concentrations can result in increased triglyceride levels and have the potential to cause hypertriglyceridemia (Harsa, 2014). The addition of PTU in HFD can also inhibit lipoprotein lipase activity. This causes triglycerides to be broken down into free fatty acids and glycerol and increases triglycerides in the blood (Pykälistö et al., 1976).

Administration Bambu Tali leaves tea at a dose of $1440 \mathrm{mg} / \mathrm{kg} \mathrm{BW}$ was able to inhibit the increase in serum triglyceride levels, but not at doses of 360 and $720 \mathrm{mg} / \mathrm{kg} \mathrm{BW}$. This is due to the dosage of $1440 \mathrm{mg} / \mathrm{kg} \mathrm{BW}$ containing more saponins, tannins, and flavonoids than the 360 and 720 $\mathrm{mg} / \mathrm{kg} \mathrm{BW}$. It means to inhibit the increase in serum triglyceride levels need higher levels of active compounds (Fatichasari, 2019).

Bambu Tali leaf tea contains flavonoid compounds that in Fatichasari (2019) research reports that flavonoids play a role in increasing the lipoprotein lipase enzyme activity, which will increase the hydrolysis of triglycerides into fatty acids and glycerol to be released into blood vessels. Flavonoids also inhibit the activity of some lipogenic enzymes, such as diacylglycerol acyltransferase (DGAT), which can inhibit the biosynthesis of triglycerides, thereby lowering blood triglyceride levels. 
In this study, orlistat could also reduce blood triglyceride levels significantly different $(\mathrm{p}<0.05)$ compared to the HFD group. This is because orlistat can inhibit gastrointestinal lipase. According to Ardiansyah et al. (2018) research, the lower the lipase enzyme activity produced, it will reduce about a third of the amount of fat absorbed from food, hence reducing the rat's triglyceride serum levels.

Based on the study results, it can be concluded that Bambu Tali leaf tea can prevent weight gain, reduce cholesterol levels, and serum triglyceride levels of rats given HFD. Thus, the Bambu Tali leaf tea can be developed as a preparation for obesity.

\section{ACKNOWLEDGEMENT}

The author would like to thank the Ministry of Research, Technology and Higher Education (KEMENRISTEKDIKTI), who has helped this research through the Student Creativity Program (PKM) with a contract letter No. 3983 / B3.1 / KM / 2018.

\section{REFERENCES}

Anas, Y., Pramesti, D., Nisa, S. W., \& Hidayati, D. N. (2017). Efek ekstrak etanol biji kedelai (Glicyne max (L.) Merr) sebagai antikolesterol dan antiobesitas pada tikus jantan galur wistar yang diinduksi MSG dan identifikasi senyawa aktivnya. In Y. Anas, D. Pramesti, S. W. Nisa', \& D. N. Hidayati (Eds.), Prosiding Seminar Nasional Sains dan Teknologi 102019 (Vol. 1, pp. 712). Semarang.

Ardiansyah, S. A., Hidayat, D. S., \& Simbolon, N. S. (2018). Uji aktivitas antiobesitas dari ekstrak etanol daun malaka (Phyllanthus emblica L.) terhadap tikus putih jantan galur Wistar. Indonesian Journal of Pharmacheutical Science and Technology, VII(1), 18-29.

Baraas, F. (2003). Mencegah serangan jantung dengan menekan kolesterol. Jakarta: Kardia Iqratama.

Fatichasari, H. F. D. (2019). Pengaruh pemberian jus buah apel manalagi (Malus Sylvestris) terhadap kadar trigliserida darah tikus putih (Rattus Norvegicus) jantan galur wistar yang diberi diet tinggi lemak. Medical and Health Science Journal, 3(2), 6. https://doi.org/10.33086/mhsj.v3i2.866

George, P., \& Nimmi, O. S. (2011). Cent percent safe centum plants for antiobesity. Internastional, $1(3), 2$.

Guyton, A. c., \& Hall, J. E. (2007). Buku ajar fisiologi kedokteran (9th ed.). Jakarta: EGC.

Habibi, A. I., Firmansyah, R. A., \& Setyawati, S. M. (2018). Indonesian journal of chemical science skrining fitokimia ekstrak n-Heksan korteks batang salam (Syzygium polyanthum). J. Chem. Sci, 7(1), 1-4. Retrieved from http://journal.unnes.ac.id/sju/index.php/ijcs

Harsa, I. M. S. (2014). Efek Pemberian Diet Tinggi Lemak Terhadap Profil Lemak Darah Tikus Putih (Rattus norvegicus). 3(1), 21-28.

Hidayat, M., Soeng, S., Wahyudianingsih, R., Ervy Ladi, J., Ari Krisetya, Y., \& Elviora, V. (2015). Ekstrak kedelai detam 1, daun jati belanda serta kombinasinya terhadap berat badan dan histopatologis hepar tikus Wistar. Jurnal Kedokteran Dan Kesehatan Indonesia, 6(4), 167-178.

Kurnia, Y. (2014). Obat-obat antiobesitas. Jurnal Kedokteran Meditek, 20(6), 12-18.

Nurrachmawati, I. (2017). Efek ekstrak daun salam (Syzygium polyanthum) terhadap glukosa darah sewaktu, kadar profil kolesterol dan diabetik kardiomiopati pada tikus diabetes melitus (Fakultas Kedokteran dan Ilmu Kesehatan, UIN Syarif Hidayatullah Jakarta; Vol. 102). https://doi.org/10.1002/ejsp.2570

Patonah, Susilawati, E., \& Riduan, A. (2017). Antiobesity activity of katuk leaf extract (Sauropus androgynus L.Merr) in mice models of obesity. Pharmacy, 14(02), 137-152.

Pykälistö, O., Goldberg, A. P., \& Brunzell, J. D. (1976). Reversal of decreased human adipose tissue lipoprotein lipase and hypertriglyceridemia after treatment of hypothyroidism. Journal of Clinical Endocrinology and Metabolism, 43(3), 591-600. https://doi.org/10.1210/jcem-43-3-591

Rantung, A. A., Umboh, A., \& Mantik, M. F. J. (2014). Hubungan hiperkolesterolemia dengan 
obesitas pada siswa Smp Eben Haezar Manado. E-CliniC, 2(2). https://doi.org/10.35790/ecl.2.2.2014.5031

Rini, S. (2012). Pengaruh pemberian diet tinggi lemak terhadap kadar trigliserida pada tikus. Univesitas Muhammadiyah Surakarta.

Rismawati, I., Usman, Pakii, E., \& Haryono, K. (2012). Uji efek antiobesitas dari susu kedelai ( Glicine max Mirril ) pada tikus (Rattus norvegicus). Jurnal Universitas Hasanuddin Makasar, 1(2), $107-110$.

Romansyah, E., Dewi, E. S., Suhairin, Muanah, \& Ridho, R. (2019). Identifikasi senyawa kimia daun bambu segar sebagai bahan penetral limbah cair. Skripsi, 6(2), 77-81.

Rusliyani, N. (2013). Ekstrak daun bambu tali (G Igantochloa Apus ) sebagai pengawet daging sapi iris selama penyimpanan dingin. Fakultas Peternakan, Institut Pertanian Bogor.

Sarifudin, A., Ekafitri, R., Surahman, D. N., \& Putri, S. K. D. F. A. (2015). Pengaruh penambahan tekur pada kandungan proksimat, karakteristik aktivitas air bebas ( a w ) dan tekstur snack bar bebasis pisang (Musa paradisiaca). Agritech, 35(1), 1-8.

Shin, D. J., \& Osborne, T. F. (2003). Thyroid Hormone Regulation and Cholesterol Metabolism Are Connected through Sterol Regulatory Element-binding Protein-2 (SREBP-2). Journal of Biological Chemistry, 278(36), 34114-34118. https://doi.org/10.1074/jbc.M305417200

Shiyan, S., Herlina, Bella, M., \& Amriani, A. (2017). Antiobesity and antihypercholesterolemic effects of white tea ( Camellia sinensis ) infusion on high-fat diet induced obese rats. Pharmaciana, 7(2), 278-288. https://doi.org/10.12928/pharmaciana.v7i2.6622

Simaremare, E. S. (2014). Skrining fitokimia ekstrak etanol daun gatal (Laportea decumana (Roxb.) Wedd). Pharmacy, 11(01), 98-107.

Sudikno, Syarief, H., Dwiriani, C. M., Riyadi, H., \& Pradono, J. (2017). The relationship of obesity index and lipid profile in 25-65 year-old adults in bogor city (baseline data of cohort study on non-communicable disease in Bogor City, West Java Province). 33(May).

Sujarwo, W., Arinasa, I. B. K., \& Peneng, I. N. (2010). Potensi bambu tali (Gigantochloa apus J Kurz) sebagai obat di Bali. Bul. Littro, 21(2), 129-137.

Tibe, F., Rimpa, M., \& Tandi, J. (2018). Uji efektivitas antikolesterol ekstrak etanol daun cincau hijau terhadap tikus putih jantan galur wistar. Farmakologika Jurnal Farmasi, XV(2).

Tjay, T. H., \& Rahardja, K. (2008). Obat-obat penting (6th ed.). Jakarta: Gramedia.

Wells, B. G., Schwinghammer, T. L., Dipiro, J. T., \& Dipiro, C. V. (2017). Pharmacotherapy Handbook, Tenth Edition. In Mc Graw Hill Education.

Wirawan, W. (2018). Uji efektivitas fraksi daun salam terhadap kadar kolesterol total tikus putih jantan hiperkolesterolemia-diabetes. Jurnal Mandala Pharmacon Indonesia, 4(1), 74-82. https://doi.org/10.35311/jmpi.v4i1.27

Yuniarti, L., Dewi, M. K., Lantika, U. A., \& Bhatara, T. (2016). Potensi ekstrak air daun sirsak sebagai penurun kolesterol dan pengendali bobot badan. Acta Veterinaria Indonesiana, 4(2), 82-87. https://doi.org/10.29244/avi.4.2.82-87

Yuniarto, A., Kurnia, I., \& Ramadhan, M. (2015). Antiobesity effect of ethanolic extract of jasmine flowers ( jasminumsambac ( 1 ) Ait ) in high fat diet induced mice : potent inhibitor of pancreatic lipase enzyme. International Journal Of Advances in Pharmachy, Biology and Chemistry, 4(1), $18-22$.

Zulviana, E., Rahman, N., \& Supriadi. (2017). Pengaruh pemberian ekstrak buah kelor (Moringa oleifera) terhadap penurunan kadar kolesterol pada darah hewan mecit (Mus musculus). 6(1), 15-20. 
